\title{
Women in Breeches and Modes of Masculinity in Restoration Comedy
}

\author{
Juan A. Prieto Pablos \\ Universidad de Sevilla
}

\begin{abstract}
The dramatic tradition that featured female characters dressed in men's costume was revived after the theatres reopened in the Restoration, with the difference that this time these roles were played by actresses. It has been argued that the contemplation of the female body reinforced the erotization of the actresses for the sake of predominantly male audiences. Their performances in "breeches roles" have also been interpreted as evidence of a progressive acknowledgement of the social possibilities of female agency. My own contention is that these roles did not only raise female agency to a level equal - if not superior, occasionally - to male agency, they also served to disrupt certain fashionable notions on the nature of masculinity, and therefore illustrate a trend that promoted new gender modes. To argue this thesis, I will focus on three comedies that represent as many stages in the development of this trend: the anonymous The Woman Turned Bully (1675), Thomas Shadwell's The Woman Captain (1680), and Thomas Southerne's Sir Anthony Love (1691), all of them featuring women wearing breeches and upsetting male order, with both comic and serious consequences.
\end{abstract}

KEYWORDS: Restoration comedy, gender identity, masculinity, breeches roles.

The motif of the woman in breeches has a long tradition in English dramatic history. It has important illustrations, in terms of both quality and quantity, in Elizabethan and Jacobean drama. According to Victor Freeburg, the motif appears in more than 8o plays written in England before 1660 (1915:91). In the Restoration, with the presence of female actors on the stage, it had a very lively revival, 


\section{J. A. Prieto Pablos}

and, according to Elizabeth Howe, "one or more roles for actresses in male clothes" were featured in 89 plays - in other words, in one out of every six plays produced in this period (1992:57; see also Wilson 1958:73).

The adoption of male disguise by women during the sixteenth and seventeenth-centuries has not only been duly noticed; it has also become the object of considerable, and often polemical, debate. Critics like Jean Howard (1988) and Juliet Dusinberre (2003) argue that theatrical cross-dressing illustrated the possibilities of female agency and autonomy, whereas others, such as Lisa Jardine (1983) and Douglas Canfield (1997), believe that most Tudor and Stuart drama was meant ultimately to reassert the validity of male supremacy and promote female subordination to male authority. I would like to contend that what cross-dressing (alongside other theatrical practices) conveyed with its iteration was the visual and textual evidence of fractures in the cultural foundations of the differences between male and female. That these fractures were the potential source of social and ideological disruption can indeed be demonstrated by the effort invested in forms of closure that were based on palatable forms of patriarchal authority. The drama produced in the second half of the seventeenth century reveals both the resilience of these fractures and the effects that their permanence provoked. This is the thesis I would like to defend, with evidence drawn from three comedies written in the Restoration period, in which female characters put on man's clothes and in doing so offer a considerable challenge to male authority.

I

One of the most significant changes introduced when the theatres reopened in 1660 was the inclusion of women actors. Once again, however, there is no consensus on how to assess the significance of this. It has been argued that the presence of women onstage, particularly when they appeared in male costume - which made all the more visible the shape of their body - foregrounded perceptions of them as objects of erotic consumption by male spectators (see Maus 1979). The erotic thrill of the contemplation of the female body does deserve consideration; yet, in order fully to ascertain its effects it would also be necessary to dissociate the body of the actress from 
the body of the character that she plays onstage. ${ }^{1}$ One could be offered for pleasurable contemplation; the other probably had a wider-reaching impact, as it touched on, and continued to question, certain ideological preconceptions regarding gender roles. This questioning was enhanced by the appearance of real women on the stage; and it was further underlined by the recurrence of breeches roles, in which female characters proved as capable of action as their male counterparts. The regular presence of actresses on the stage can thus be construed as evidence of the occupation by women of at least one niche in the public sphere; and the nature of the characters they acted, often assertive and independent, attests to the fact that female agency had gained public recognition and acceptance, as Margaret MacDonald noted in her classic The Independent Woman in the Restoration Comedy of Manners (1976).

I would also like to contend that, in most Restoration drama, female agency was no longer questioned. A general survey of the plays produced in this period clearly shows that the number of submissive women is far lower than the number of resourceful ones; and the most outstanding and remarkable female characters, hence the more attractive ones, correspond to the latter type, at least until the 169os. General concerns centred, rather, on the other sex - or the other gender - and on the features that could define male identity, once women had proved capable of taking over some of the roles hitherto exclusively reserved for men.

Mark Breitenberg (1996) has argued that masculinity was in a permanent state of anxiety in the early modern period. One might have the impression that, if there was a moment in which this anxiety was least perceptible, it must have been during the Restoration period, when, according to Andrew Williams, the libertine or rake "established himself as a principal [even hegemonic] figure of male identity" (1999:95). However, Williams himself acknowledges that the prevalence of the libertine was constructed at the cost of undermining other versions of masculinity (1999:106-107). Restoration drama provides a wide gallery of types that were branded "effeminate": witwouds and fops, country bumpkins and citizens, and humorous and lusty old men are the most recurrent,

\footnotetext{
${ }^{1}$ On the possible effects of this contraposition or "conflict between subjectivity in the drama and visual objectification in the theater," see Rosenthal (1996).
} 


\section{J. A. Prieto Pablos}

though not the only ones. Anxiety can be recognized in the eagerness with which these other types were subjected to public derision by the libertine and his supporters, and therefore in the manner in which masculinity was forced to depend on the exclusion of weaker or softer models of representation. However, even if the figure of the libertine was indeed popular, it was by no means hegemonic, or unquestioned. As Robert Hume contends, "that the libertine ideas are present in the comedies [of the Restoration] we must agree, but no one has shown that the values of the plays are predominantly libertine, nor does such a demonstration seem possible" (1977:29). ${ }^{2}$ In the established picture of Restoration drama there is an excessive emphasis on characters such as Horner in Wycherley's The Country Wife or Dorimant in Etherege's The Man of Mode; but a rough estimate of the gallants appearing in Restoration comedy would suggest that the libertine comprises only one-quarter. So, if we see the libertine as a hegemonic model of masculinity we simply distort the full and very complex panorama of male representation. With regard to The Country Wife, Hume remarks that "I do not agree with the critics who see [Harcourt and Alithea] as a moral norm for the play. But are [they] somehow shown up or derided? Let the critic prove it who can" (1977:29). Yet in the play Harcourt is indeed an alternative to Horner, and a more positive and profitable model; and Restoration drama has many more Harcourts than Horners.

The popularity of the libertine has generally been attributed to a reaction against the restraints imposed during the Interregnum; I would like to suggest that it was also a response to the challenges posed by the vibrant and increasing presence of women in the public arena. In this process, the libertine became a hyper-masculinized version of man, not unlike the hyper-muscular, macho-men played by Arnold Schwarzenegger or Silvester Stallone in another critical period in the history of masculinity. The libertine is not treated derisively, like the fops and cuckolded citizens; but its ideological fractures are frequently exposed. Moreover, these fractures are not perceptible only in the libertines; they can be found in the Harcourts, too. They reveal to what extent masculine values were being scrutinised and questioned, and they justify the full extent of male anxiety in this period.

\footnotetext{
${ }^{2}$ For further discussion of this topic, see Weber (1986).
} 
These fractures are most perceptible in the plays in which male characters must face the challenge posed by women who are dressed like, and behave like, men. In some of these plays, the tension focuses not so much on whether these women will succeed in their plots (it is a foregone conclusion that they will) but on whether - or how - the men will successfully confront them. The challenge is particularly stinging, because both parties fight with the same weapons, yet the male competitor is the one with most at risk, being the one who in theory is better endowed with the ability to use these weapons. The obvious implication is that only those who come off unscathed would stand as suitable representations of masculinity. What makes these plays interesting is that even the gallants who succeed in challenging the cross-dressed women cannot avoid coming through without obvious scratches in their masculine pride.

This is what happens in the plays I have selected for analysis. They are the anonymous The Woman Turned Bully, Thomas Shadwell's The Woman Captain, and Thomas Southerne's Sir Anthony Love. They represent a small but significant number of plays featuring women in breeches. They also belong to different periods, and therefore show that the issues under question endured throughout the Restoration, even under different ideopolitical conditions.

\section{II}

The Woman Turned Bully was premiered and printed in 1675 -the same year in which Wycherley's The Country Wife was produced. The title role was very likely acted by Mary Lee, a young actress who had already played at least one breeches role and would continue to do so for at least three more years. ${ }^{3}$ She had quickly risen to lead parts, and specialised in strong and resourceful women. These are

\footnotetext{
${ }^{3}$ She acted the blackamoor Nigrello/Clothilda in Settle's Love and Revenge (1675), warrior princess Amavanga in The Conquest of China (1676), and shepherd Astatius in the anonymous pastoral The Constant Nymph (1677); she also played an occasional breeches role in Durfey's Madam Fickle (1677) and Leanerd's The Counterfeits (1678). According to Howe, "in the character of Madam Fickle Durfey seems to have deliberately recalled Mrs Lee's part two years before as Nigrello in Elkanah Settle's tragedy Love and Revenge" (1992:77); but some of the features of the character seem to be inspired also by Betty in The Woman Turned Bully (see Mora E al., eds. 2007:56-58; and Mora 2008).
} 


\section{J. A. Prieto Pablos}

the features, too, of the character she plays in The Woman Turned Bully. Betty Goodfield is a young country woman who, when she finds that her mother intends to marry her to a country bumpkin, escapes to London in order to find a more suitable match. To protect herself from the hardships of travel, she and her maid resolve to wear man's costume. Once in London, she realizes that, in order to achieve her plans, she must not only look like a man, she must also act like one. She discusses the matter with her maid, and decides that she must imitate the manners of the only London men she knows about, the gallants that populate the plays she has read at home. This proves to be a two-edged weapon. On the one hand, her notion of the London gallant is based on the extravagant rakes of contemporary comedy, who pepper their speech with fashionable oaths and nonsensical phrases and seek to imitate the bullies of the London underground. As her maid observes, Betty "must learn to swear more like a gentleman" and spend the day "drinking, gaming and wenching" (1.2.32-33, 79), or she'll never pass for a gallant. ${ }^{4}$ And Betty, who knows her plays well, immerses herself in her character with outstanding vitality and success. On the other hand, however, it is quite obvious in The Woman Turned Bully that the dramatic rake is an artificial construction, and is perceived as such by the two young gallants, Truman and Betty's own brother Ned. Neither suspects that she really is not a man, but nor can they fathom the reasons that make such a young blade act so extravagantly; thus her behaviour is a continuous source of puzzlement. These effects are most perceptible in the man Betty chooses as her future husband, the aptly-named Truman. He calls her "a witty wild frolicking rascal" (5.2.29) but also confesses that he rather likes his/her "humour" (2.1.201), and feels strangely attracted to him/her. This attraction has only the lightest suggestion of homoeroticism; what makes it especially poignant is that he - supposedly a "true man" - is thrilled by someone who is so obviously a bully, and not even a "true" one.

Precisely because she is an artificial bully, Betty Goodfield becomes the satirical instrument for the exposure of several male types. The most obvious is the fop, who believes that by adopting fashionable oaths and abusive expressions he will find accommodation among the true wits. The second and most

\footnotetext{
${ }^{4}$ All references to this play are from Mora $\mathcal{E}$ al. (2007); they indicate act, scene and line number.
} 
significant target is the source of the fop's imitation, the "brisk" gallant who, instead of wooing his mistress with courteous words, chooses to do so by "railing." This character type appears in plays such as James Howard's The English Monsieur (1663), Etherege's The Comical Revenge (1664), and William Cavendish's The Humorous Lovers (1667). In none of them is his behaviour wholeheartedly criticized. ${ }^{5}$ However, Betty has them in mind when she comments ironically: "[they] have wisely considered love has been made so common, trite, and out of fashion that [...] the damned name [of love] is hateful; and both sexes have agreed [...] to disown the scandal of love and call it gallantry, mirth, and raillery" (2.1.190-195). This criticism is cautious and yet quite serious, because the brisk lover is a variant of the Restoration rake, and a type that appears as a role model in much of the drama of the period. Its appeal is made evident in that Truman himself adopts this role. He does so only briefly, and to good purpose - to prevent the marriage of Betty's mother with an old miser - and, to be fair, he is not quite successful:

MADAM GOODFIELD: [...] - But, sir, pray put none of your London tricks on me. I fear you do but exercise your wit upon me; for you town gallants love to flout poor country gentlewomen to make you sport.

TRUMAN: If thou delayst one minute longer, widow, I'll vow to blast thy reputation, kill all that dare pretend to you, and at last, in spite of thyself, enjoy thee and then jilt thee.

MADAM GOODFIELD: Goodness! What pretty words you gentlemen have. Jilt me? Well, that must be some fine thing, it sounds so well. Jilt - I might have lived in Derbyshire to Methusalem's age, and not have heard such fine things.

TRUMAN: Uds precious, widow, what mean you? Swear instantly to be mine or, I vow, I will prosecute what I told you. (5.1.87-97)

Truman only feigns to be a rakish gallant; but the threats are obvious, and to spectators of the Restoration theatres they must have had clear echoes from earlier plays, and from real life. To people like

\footnotetext{
${ }^{5}$ In Howard's play, the rake is Wellbred, "A wild gentleman" who is a relentless gamester and only proposes to the heroine when he has run out of money. In Etherege's, it is Sir Frederick Frolick. And in Cavendish's, it is Boldman, of whom Canfield says: "Lady Pleasant strips Boldman of his cocksureness and causes him to be publicly and mercilessly mocked" (1997:47); but in the end he retaliates against her and has the upper hand in his relationship with her.
} 


\section{J. A. Prieto Pablos}

Truman, the brisk and rakish lovers of Restoration comedy must have stood as particularly controversial examples in the definition of men's most desirable roles: a kind of behaviour based on verbal and physical abuse, combined with a neglect of the moral principles that would make him refrain from such abuse, suggests that the supremacy of the male and the "necessary" submission of the female can only be effected by force. For this reason alone it deserves to be criticized and discarded.

The Woman Turned Bully also suggests that the survival of the bully may prove to be socially disruptive in a wider sense. In her encounters with the gallants, Betty Goodfield not only forces them to agree to risk their lives in a duel - that is, to an act that can symbolically be construed as a challenge to the physical integrity and survival of worthier gender models - she also - and more importantly - manages to destabilize their psychological or emotional integrity, with the result that Truman loses control, and almost becomes another bully, on several occasions. Remarkably, Betty culminates her own bullying practice when she is no longer in breeches (though she is once again in disguise), as if the "infection" of her male costume still affected her behaviour and had indeed turned her into "a petticoat Hector" (5.2.58).

Whether in breeches or in petticoats, Betty Goodfield acts according to her "wild" humour. But this is precisely what Truman likes about her. As he declares, he prefers a woman "full of air and gaiety to the utmost extent," rather than a demure one (1.1.160-161). She is certainly chaste, but is neither silent nor obedient, nor will she be content with assuming a passive role in her life; and, incidentally, she also has proved that she is not at all inferior to any man. The final challenge for Truman lies in accepting this. It is not an easy task: when Betty reveals her true identity, his first response takes the shape of an open, even if mild, threat:

TRUMAN: Well, madam, by this fair hand -

\section{Takes her hand and kisses it.}

I vow I can never forgive the injury you have done yourself and truth in such a character; and I am resolved, ere long, to be revenged on ye for it, to some purpose.

BETTY GOODFIELD: No threatenings, I beseech you, sir. Your great threateners are ever the last performers. 
Ned GoOdFIELD: Are you not much surprised, Jack, at this discovery?

TRUMAN: Extremely; but more pleased.

And Ned Goodfield's comments evince a sexualized form of male dominance, as he removes their coming duels from the field to their private apartments:

BETTY GOODFIELD: Aye, aye, let's return. Now my duels are over, I have no more occasion for the open field.

NeD GoOdFIELD: True, sister; a private apartment is much more proper for what's like to follow.

But Betty's conditions state her preferences quite plainly:

TRUMAN: But as we walk, madam, how are you pleased I shall treat ye in this disguise? As a mistress, or a friend?

BETTY GOODFIELD: As a friend, sir, for life. If you appear too servile while I am in breeches, you will encourage me to wear 'em always. (3.1.250-278)

Once Truman agrees to these conditions, the play slides smoothly to its happy end, with the promise of a marriage based on an equitable partnership, wherein she will by no means be a submissive wife and he will not be an abusive or repressive husband. For Truman, the latter condition will be the easier part of their contract, because he has offered sufficient evidence that he is a courteous and mildmannered man; the former may seem to be harder, because, by granting freedom to Betty, Truman must also renounce some of the authority that was traditionally assigned to men and must therefore risk being perceived as less than a man.

\section{III}

Four years after the premiere of The Woman Turned Bully, Thomas Shadwell provided the Duke's Company with the script of The Woman Captain. This time the title role was assigned to Elizabeth Barry, at the time a young promising actress who had already showed a natural inclination for high-spirited comic characters. Her time for tragedy had not yet come: it would start in 1680 with Otway's The Orphan, then it would continue with a steadily rising career that would make her one of the greatest actresses of her time. 


\section{J. A. Prieto Pablos}

She would also become the first actress to hold shares in her company, thus breaking the barrier that made all women hirelings, with no more rights than any young male actor. In the 1670 s she had already acted Hellena in Behn's The Rover and Olivia in Durfey's The Virtuous Wife, in both of which she briefly donned man's clothes; Mrs Gripe, the Woman Captain, was her third leading breeches role.

The play shows the extent of Shadwell's commitment to Whig moral reform. One of the plot lines centres on Sir Humphrey Scattergood, a young libertine who has just come of age and finally been granted access to his dead father's wealth and now resolves to devote his time to extravagant debauchery. To a great extent, this story can be read as a morality play, as his prodigality leads him to bankruptcy and eventually to a recognition of his faults and repentance. This plot line alternates with and only marginally touches on the story of Mrs Gripe, a young wife to an old jealous miser who keeps her locked in her room. She patiently suffers her husband's abuse; but, when Sir Humphrey and his band of debauchees invade Gripe's house with the intent to kidnap her, she slips away and plots a revenge that is initially intended only for her husband but eventually includes a whole troop of men. With the assistance of her brother's sergeant, she puts on her brother's clothes (he is away, fighting in Flanders) and assumes his identity. This is achieved both due to their close resemblance and to her capacity to accomplish the manners of an army officer:

MRS. GRIPE. Am I compleatly set out like a young Officer? Do my Brother's Accoutrements fit well upon me?

SERJ[EANT]. They become you admirably; you are as brisk, as fierce an Officer as the best of 'em; and so like your Brother, 'tis amazing; had I not been privy to your Design and his, I should have sworn you were my Captain. (3.1.452-458) ${ }^{6}$

In this costume, she goes to old Gripe to demand a settlement for separation. When he refuses, she has him and his servant beaten and enrolled in the army, and both are taught to march and follow the sergeant's orders, and threatened with being sent to the war in Flanders, where they will surely die. Sir Christopher Swash and his two bully companions then join the company. They spend their

\footnotetext{
${ }^{6}$ All references to this play are from Thomas Shadwell, The Woman Captain: A Critical Old-Spelling Edition (1993).
} 
nights drinking, swearing, breaking windows and beating citizens and constables, ${ }^{7}$ and she offers to help them evade the law by giving them soldier's clothes; but then they find that they have unwittingly become members of Mrs Gripe's troop, and they are beaten into accepting her orders. The effects of her behaviour extend also to the world of rakish Sir Humphrey and his dissolute companions, when she steals "the affection of the[ir] three prostitutes" and thus manages to "discredit their pride in manhood and rank" (Hughes 1996:222).

Robert Hume labels this play a light-hearted farce, intended merely for entertainment (1976:333). ${ }^{8}$ But he seems to ignore the fact that farce, like comedy, can also prove to be a comment on reality by way of its sublimation of certain social fantasies. Such is the case with The Woman Captain, in its enactment of the fantasy of a woman emasculating husbands and other disreputable males for the pleasurable consumption of male spectators who of course do not recognise themselves portrayed in neither type on stage. In the context of Restoration comedy, which is merciless with regards to these character types, the punishment suffered by them is deserved, and is the more stinging and humiliating because undertaken by a woman. But the play has a moral purpose, too, which is explicitly remarked in the play's closing lines:

MRS GRIPE. Now all ye Husbands, let me Warn ye!

If you'd preserve your Honours, or your Lives;

Ne'er dare be Tyrants o're your Lawful Wives. (5.1.679-681)

Furthermore, the occurrence of the word "tyrant" suggests that the moral has political and ideological overtones. Shadwell's ideological agenda is recognizable also in the kind of resolution he provides for Mrs Gripe. As there is no possibility of divorce, she obtains a legal separation that grants her a wealthy independent life. This is all the more remarkable inasmuch as the play offers no prospect of her

\footnotetext{
${ }^{7}$ This type of foppish rake had been the target of Shadwell's criticism since very early in his career. Already in his Preface to The Royal Shepherdess (1669), he complained on how "it pleases most [spectators] to see Vice incouraged by bringing the characters of debauch'd people upon the Stage, and making them pass for fine Gentlemen who openly profess swearing, Drinking, Whoring, breaking Window, beating Constables, \&c." He would continue his campaign against them in The Squire of Alsatia (1688) and The Scowrers (1691).

${ }^{8}$ This opinion is shared also by Rothstein and Kavenik (1988:233).
} 


\section{J. A. Prieto Pablos}

finding - or wishing to find - a new male partner. Shadwell's play is quite exceptional too in that it ends with no acceptable marriage; and yet this is a logical consequence of what has gone before, if we consider that the play features no suitable male exemplar. Or rather, there is one, but he is Mrs Gripe's brother, a soldier fighting for his country, and whom she represents vicariously. In the immediate context of the political unrest provoked by Titus Oates's revelations and the impending Exclusion Crisis, it is also tempting to read Shadwell's gallery of male types as representative of the collapse of the gender values that had prevailed at Court, and as suggestive of a need to give way to a new value system, by the force of arms if necessary. Mrs Gripe's final couplet thus acquires subtler - and more significant - nuances, and goes beyond a mere declaration in favour of marital or domestic rights. ${ }^{9}$

\section{IV}

The third play in my list, Sir Anthony Love, was premiered in 1690, ten years after The Woman Captain. The title role was this time assigned to Susanna Mountfort. Her fellow actor Colley Cibber remarked of her that "while her Shape permitted, she was a more adroit pretty Fellow, than is usually seen upon the Stage" and that "People were so fond of seeing her [as] a Man, that when the part of Bays in the Rehearsal, had, for some time, lain dormant, she was desired to take it up, which I have seen her act with all the true, coxcombly Spirit, and Humour, that the Sufficiency of the Character required" (1740:99). This comment suggests that - at least to some extent - the presence of women in breeches was losing some of the sexualized overtones that it allegedly had at the beginning of this period. But it can also help understand Mountfort's success in her role as Sir Anthony Love.

Mountfort had started her career in 1681 and had already played some leading characters, but Lucia/Sir Anthony Love was

\footnotetext{
9 Staves sees The Woman Captain only as "a play about liberty cast in domestic terms" (1979:170), and seems to ignore its more immediate political implications. Rothstein and Kavenik do, somewhat more timidly, when they comment that "no doubt the void of authority and its ersatz expression through distorted social institutions [...] represented to Shadwell the state of England in 1679" (1988:232), but they argue that this was motivated by personal resentment.
} 
the role that brought her fame. It was undoubtedly a great challenge. She needed to make it credible that a woman could pass for a young rake and gain admittance to the close circles of other rakish gallants without raising suspicions about her true identity. But then at the same time, and most importantly, she needed to play it so that at times her character would be seen, not as a woman playing a man, but as a man acting like a man - or as a conflation of both genders, or even as a deconstruction of gender differences. This was essential in order for the audience to understand the scenes where she has fully become a rake, and therefore thinks and acts like a rake.

Two episodes can better illustrate this point. At the very opening of the play, she appears already dressed in man's costume, commenting to Waitwell (her Governor or instructor) on how proficiently she has attained one of her goals. To Waitwell's remark that she can "so perfectly act a Cavalier" that she "wou'd carry all the Women before [her]," she adds with great confidence that she can also "drive all the Men before [her]" as "I am for Universal Empire and [...] wou'd be fear'd, as well as lov'd: As famous for my Action with the Men, as for my Passion for the Women" (1.1.8-14). ${ }^{10}$ Here spectators are prompted to see a woman in breeches, just like in The Woman Turned Bully or The Woman Captain. The very extravagance of her behaviour foregrounds her femaleness and evinces that she is a woman in disguise.

Soon after, however, Lucia's behaviour and words become less and less distinguishable from those of her male companions, and her female identity is subsumed beneath her adopted male identity, to the extent that what the spectators are invited to perceive is not a female character (Lucia) acting a male (Sir Anthony), but a female actress (Mountfort) acting in all respects like a male actor playing a male character (Sir Anthony). This, in my opinion, is quite perceptible in some conversational exchanges between her and Valentine, in which there is no textual evidence of "femaleness" in her contributions, nor any suggestion of sexualization of either contents or attitude, as, for example, in the following passage, where Sir Anthony, Ilford and Valentine comment on a Pilgrim who has just come onstage:

${ }^{10}$ All references to this play are from Southerne's Works (1988). 


\section{J. A. Prieto Pablos}

VAL[ENTINE]. Whom have we here?

SIR ANT[HONY]. A Brokeing brother of Bethlehem, with all his Frippery about him!

VAL. One of that traveling Tribe, without their Circumcision.

SIR ANT. Of Christian Appellation, a Pilgrim.

VAL. 'Tis a senseless Constitution of Men!

SIR ANT. Who make themselves Mad, to make the rest of the World Fools, by finding a Faith for all their Fopperies.

VAL. How can they pass upon the World?

SIR ANT. As other Constitutions, and Orders of Men as senseless, pass; that are founded too in as much Cozenage and Roguery as this can be.

ILF[ORD]. You are an Enemy of Forms, Sir Antony.

SIR ANT. Oh, Sir, the Virtue of the Habit often covers the Vices of the Man: There's Field enough in England to find this in, without the Abby-lands, Gentlemen.

ILF. Weeds are the general growth of every Soil.

VAL. How many Fools in the State, and Atheists in the Church, carry themselves currant thro' their Congregations and Clients, to great Employments; and, being arm'd only with the Authority and Countenance of their Cloathing, secure themselves from the discovery and censure of the Court and Town?

SIR ANT. There are disguises, I grant you, worth a sensible-man's putting on; but a Pilgrim's Habit is as ridiculous as his Pretence; and I wou'd no more wear a Fools Coat, to be thought devout; than be devout for the sake of the Livery.

ILF. Fools are the Gutts of all Churches, and make the bulk of every Opinion. (1.1.149-176)

Their conversation plays on the notion of concealed identity, but it bears only marginally on Sir Anthony's own disguise. Nothing in it suggests that her own identity as a woman is played upon, textually or visually; and her participation is quite undistinguishable from that of her companions. To all appearances, this reads like any other conversation by gallants in any other Restoration comedy: and Sir Anthony is just one of them. 
There are, of course, other episodes in which sexual innuendo plays a significant role, especially when there is an evident contrast between the characters' expectations and the spectators' awareness of Sir Anthony's natural limitations. Such is the case, for example, with Ilford's fears that Sir Anthony may ruin his plans to marry Volante - or worse, may seduce her; and, in a remarkable turn of wit, with the Abbe's disappointment when he finds that Sir Anthony, the object of his lust, is a woman in disguise. But the main significance of the play resides in Lucia's full appropriation of the features that define a typical rakish gallant, and in the process by which the character is perceived by the audience as a man, or as a conflation of both man and woman.

But Sir Anthony is not just a man; he is a rake. The full extent of this qualification is perceived in her contributions to the comic closure to Ilford's love conflict and to her own relationship with Valentine. After plaguing Ilford with Sir Anthony's rivalry for Volante's love throughout most of the play, she finally helps him via the very questionable method of faking her marriage and then letting Ilford take her place in Volante's nuptial bed. Being an honest gallant, Ilford does not play along to the full and denounces Sir Anthony to Volante, who in appreciation of his courtesy shifts her affection from Sir Anthony to him; and thus this part of the story ends happily, and with no blemish to Volante's honour and reputation. But Lucia's/Sir Anthony's plan had no such moral qualms.

With regards to Valentine, Lucia has an even more radical and more successful plan. As Lucia, she is a new iteration of the typical runaway girl in pursuit of the man she loves, like Betty Goodfield in The Woman Turned Bully. Unlike Betty, who wishes to avoid the prospect of an unwanted marriage, Lucia has escaped the bonds to "the worst of Fools; a Singular, Opinionated, Obstinate, Crookedtemper'd, Jealous-pated Fool" (1.1.29-30) to whom she was sold when she was still a girl. She has obtained some means for independence, as she has run away to France with 500 pounds stolen from him; but she has no viable prospect of life with Valentine, an impoverished immigrant. She therefore devises a plot to have Valentine marry Floriante, and Valentine in turn helps her to a sizeable separate maintenance from her former keeper, in their 


\section{J. A. Prieto Pablos}

common understanding that Lucia is better off as Valentine's lover than as his wife.

That she should prefer a life as a mistress rather than as a wife may be a source of distress for those critics who expect a morally orthodox resolution - more particularly so, as Helga Drougge notes, because her sexuality is not presented as disgusting or demonic (1993:548). It is, however, a suitable option inasmuch as it guarantees a life of independence. Through her lack of concern for the moral implications of her actions the play shows the depth of her assimilation of libertine ideas, and hence of masculine values. Drougge also comments that "Lucia is unique on the patriarchal Restoration stage: a female rake who is successful in all her schemes, loves liberty above all things, and does mean lewd liberty" (1993:549). In her male costume, she can further enjoy "the energy and aggressiveness of the male sex role," and in the process she evinces that maleness is "not intrinsic but constructed" (1993:550). However, despite all appearances, the play does not fully condone libertinism. Its author does juggle with the response that the figure of the rake had elicited in Restoration audiences as a resourceful, witty and unorthodox hero, and sublimates its qualities through the figure of a female rake; but he also provides an alternative, albeit less exciting, counterpoint in the character of Ilford. He is continually mortified by the threat posed by a seemingly irresistible rival, and like Truman in The Woman Turned Bully - at times he even loses his composure; but he remains an honest and constant gallant, and is presented as a better suitor to women like Volante who can be tempted by the dangerous allure of the rakish gallant.

\section{V}

A common distinction between tragedy and comedy states that, while the former plays on reality and is bound by the constraints posed by that reality, the latter plays on fantasies of wish fulfilment. If we accept this premise, then these three comedies can be seen as representations of fantasies of female empowerment, expressed through women who decide to adopt men's customs and successfully engage with them to fulfil their plans. This is a perspective that many people may adopt nowadays. As regards Restoration audiences, however, this requires assuming that female 
spectators were a substantial part of those audiences, or that the number of male and female spectators who shared these fantasies was sufficient to make them the intended audience. Neither assumption, however, can be confirmed by the scant evidence available. ${ }^{11}$ Rather, it seems more sensible to assume that male spectators were both the majority and the preferred target in Restoration performances; particularly so when the authors of these plays were men, too. To them, the fantasy could be realized through the figure of the woman who is willing to give up all for the man she loves - as in The Woman Turned Bully and Sir Anthony Love, and as in many other plays in which women take the lead; but this, I believe, would not be gratifying enough.

To explain my thesis, let me turn over my own definition of comedy and posit that comedy can also foreground common anxieties or fears. The way in which these anxieties are resolved can elicit a pleasurable relief, when it is an agreeable one; or it can evince the existence of permanent ideological fractures or fissures, if the resolution proves to be unsatisfactory. From this point of view, all three plays discussed here show that masculinity was a common source of anxiety, focalized on men who must confront the prospect of women talking over and depriving them of the qualities that were hitherto regarded as exclusively male. Yet they also show that patriarchal or male supremacy was not being called into question, ultimately. In my opinion, these two closely related concepts, patriarchy and masculinity, must be separated - even if only for analytical purposes. If patriarchy is based on the notion that men must wield power hegemonically, and if the hegemonic definition of manhood is "a man in power, a man with power, and a man of power," as Michael Kimmel famously asserts (1997:28), then patriarchy and manhood are indeed endorsed in these plays: it is the men who hold the power; women can too, but only as long as they assume male identities. Moreover, their adoption of that identity is always temporary (they must eventually relapse or retreat into their "natural" role), and in the process they demonstrate the full extent of their assimilation of male superiority. And last but not least, in none of these plays is there an explicit vindication of the right of women to wield some power as women.

${ }^{11}$ This is still so, despite Lowenthal's too general assertion that "the late Restoration playhouse was filled with women" (2003:111). 


\section{J. A. Prieto Pablos}

The source of anxiety lies, not in whether men should maintain their supremacy, but in the grounds on which it could be maintained, and in the type of man that could best represent it. The basis for the first question is well illustrated in these plays featuring women who can act like men - even better than some men - for as long as they wish, undiscovered by the men they meet. Biologically, man and woman remained different; in some fields of action, however, women proved as capable as men. The success of the woman in breeches is the last step in a growing recognition of women's agency in Restoration drama, and illustrates what to Hitchcock and Cohen was "a gradual breakdown of older forms of gender identity and behaviour" (22). If women could encroach on and eventually replace men in these fields of action, it was necessary to assume that such fields were not intrinsically and uniquely masculine.

As Breitenberg asserts, quoting Judith Butler, cross-dressing was one among several other subversive resources that "expose the contingent acts that create the appearance of a naturalistic necessity" (1990:33). But even if masculinity was based on contingent rather than natural or biological values, it was necessary to ascertain some grounds for its distinctiveness and to identify a suitable model (or a suitable set of models) of masculinity. ${ }^{12}$ The plays I have analysed show that the search for the "new man" was still in progress throughout the Restoration. Certain models were quickly disposed of: old misers, citizens, fops and witwouds were branded as effeminate and unfit for marriage with young ladies of quality, virtuous, witty and wealthy. Naturally, women in breeches never endorsed any such male types by deigning to impersonate them. That their goal was to pass for a young gallant shows quite clearly that this was also their most desirable male model. But even in this there is no evident consensus. The libertine was indeed very popular at the time; and the following passage from Sir Anthony Love shows how the equation between libertinism and manliness was still applicable on the Restoration stage in the early 169os:

SIR ANT. Then you are not one of those fine Gentlemen, who because they are in love with one Woman, can lie with nobody else?

${ }_{12}$ On the resilience of the biological distinctiveness of man and woman in the hierarchical organization of gender differences, see Kimmel (2000:21-46). 
VAL. Not I, Faith Knight; I may be a Lover, but I must be a Man.

$(3 \cdot 5 \cdot 41-43)$

However, both this play and The Woman Turned Bully, and to a lesser extent The Woman Captain, feature the rake's natural aggressiveness as potentially disruptive. This was evident even before the emergence of the repentant or penitent rake in the sentimental comedy of the 1690 and early eighteenth century. ${ }^{13}$

All three plays coincide also in offering a more acceptable, albeit less thrilling, alternative in the figure of the honest and constant gallant. Truman (in The Woman Turned Bully), Mrs Gripe's brother (in The Woman Captain), and Ilford (in Sir Anthony Love) are further reproductions of the type represented by Wycherley's Harcourt, so often ignored in critical assessments of The Country Wife because of the attractiveness of the rakish Horner. Only Truman, however, stands out as a desirable partner since the beginning: Mrs Gripe's brother is defined by his absence, and Ilford's relevance is overshadowed by Valentine's and only becomes an option for Volante after she is forced to accept that Sir Anthony is no longer available.

Truman and Valentine coincide, nonetheless, in admitting a type of gender relationship based on companionship rather than on the imposition of male superiority. Marriage is undesirable for Lucia/Sir Anthony - as it is for so many other characters in Restoration drama - because it is based on the submission of the wife to the husband. As Valentine's lover, she can guarantee that her relationship will not be based on old conditions; what she, like Mrs Gripe, wants is sensibly to secure some independence by means of a separate maintenance. But even in the event of marriage it is to be expected that new conditions will be negotiated. In this respect, Restoration comedy was advancing the type of marriage contract that Mary Astell would advocate at the turn of the century (see Hitchcock and Cohen 1999:13; Stone 1979:181-191), and at the same time confirmed the principles of mutuality that had emerged earlier on, according to Marianne Novy (1984), in Shakespeare's drama.

\footnotetext{
${ }^{13}$ On the "penitent rake" as a character type in Restoration drama, see Berkeley (1952). He did not include The Woman Captain among the 23 plays featuring the type, but Sir Humphrey Scattergood fully represents it. See also Williams (1999:94-114) for an enlightening contrast with the "unrepentant libertine."
} 


\section{J. A. Prieto Pablos}

\section{VI}

The plays I have analysed show that the new and most desirable modes of masculinity must entail the recognition of female agency and the need to redefine gender relations. They show no evidence of Breitenberg's bleak picture of "men whose responses to women's social and economic gains and to the changes in gender roles take the form of retrenchment in traditional values, misogynistic scapegoating of women for the supposed failure of the nuclear family, aggression and violence toward women that masks their own insecurity and vulnerability" (1996:33). What can be perceived is a more open-minded response, and a widespread one at that, which led to the end of a model of gender hierarchy based on the assumption that woman was naturally inferior to man. In Tudor England, gender, states Anthony Fletcher, "was still a cosmological principle. It shaped sex [...] Woman was seen as a creature distinct from and inferior to man, distinguished by her lesser heat" (1995:xvi). Politically, women's inferiority was confirmed by the analogy between state and family, with the father or husband acting as absolute rulers. In late Stuart England, however, there is growing evidence that woman's agency and capability was proving this wrong.

Michael McKeon (1995) has argued that the old patriarchalism entered a stage of crisis in the second half of the seventeenth century, in line with the crisis and eventual dismissal of absolutism. Patriarchalism did not collapse, however; the old, vertical model was replaced by a new, non-hierarchical horizontal one that acknowledged for women a position alongside men yet separated their activities within - using Habermas' terminology - specialised spheres: the public sphere was reserved for men, while the private or domestic sphere was the woman's domain. ${ }^{14}$ Breitenberg, rather pessimistically, contends that "masculine anxiety [...] operates on at least two significant levels: it reveals the fissures and contradictions of patriarchal systems and, at the same time, it paradoxically enables and drives patriarchy's reproduction and continuation of itself" (1996:2). And we may have to agree with him. In the horizontal patriarchal system, the redefinition of roles would confirm the superiority of man over woman once again, and would constrain

\footnotetext{
${ }^{14}$ For further analysis based on this perspective, see also Kimmel (2005).
} 
(3) ederi 22 (2012)

women to seclusion and submission. But Restoration drama shows that, for a while, other options were possible.

\section{References}

Berkeley, D. S. 1952. "The Penitent Rake in Restoration Comedy." Modern Philology 49: 223-233.

Breitenberg, Mark 1996. Anxious Masculinity in Early Modern England. Cambridge: Cambridge University Press.

Butler, Judith 1990. Gender Trouble: Feminism and the Subversion of Identity. London: Routledge.

Canfield, Douglas J. 1997. Tricksters and Estates: On the Ideology of Restoration Comedy. Lexington: University of Kentucky Press.

Cibber, Colley 1740. An Apology for the Life of Colley Cibber. London.

Drougge, Helga 1993. "We'll learn that of the men': Female Sexuality in Southerne's Comedies." Studies in English Literature 1500-1900 33/3: 545563.

Dusinberre, Juliet 2003. Shakespeare and the Nature of Women. Houndmills: Palgrave Macmillan.

Fletcher, Anthony 1995. Gender, Sex and Subordination in England 1500-1800. New Haven: Yale University Press.

Freeburg, Victor 1915. Disguise Plots in Elizabethan Drama: A Study in Stage Tradition. New York: Columbia University Press.

Hitchcock, Tim and Michèle Cohen 1999. English Masculinities 1660-1800. London: Longman.

Howard, Jean 1988. "Crossdressing, the Theatre and Gender Struggle in Early Modern England." Shakespeare Quarterly 39/4: 418-440.

Howe, Elizabeth 1992. The First English Actresses: Women and Drama 16601700. Cambridge: Cambridge University Press.

Hughes, Derek 1996. English Drama 1660-1700. Oxford: Clarendon Press.

Hume, Robert D. 1976. The Development of English Drama in the Late Seventeenth Century. Oxford: Oxford University Press.

Hume, Robert D. 1977. "The Myth of the Rake in 'Restoration' Comedy." Studies in the Literary Imagination 10/1: 25-55.

Jardine, Lisa 1983. Still Harping on Daughters: Women and Drama in the Age of Shakespeare. Sussex: Harvester.

Kimmel, Michael 2005. "From Lord and Master to Cuckold and Fop: Masculinity in 17th-Century England." The History of Men: Essays in the 


\section{J. A. Prieto Pablos}

History of American and British Masculinities. New York: State University of New York Press: 125-142.

Kimmel, Michael S. 1997. "Masculinity as Homophobia: Fear, Shame, and Silence in the Construction of Gender Identity." Eds. Mary M. Gergen and Sara N. Davis. Toward a New Psychology of Gender. London: Routledge: 223-242.

Kimmel, Michael S. 2003. The Gendered Society. New York: Oxford University Press.

Lowenthal, Cynthia 2003. Performing Identities on the Restoration Stage. Carbondale: Southern Illinois University Press.

MacDonald, Margaret L. 1976. The Independent Woman in the Restoration Comedy of Manners. Salzburg: Institute für englische Sprache und Literatur.

Maus, Katharine Eisaman 1979. "'Playhouse Flesh and Blood': Sexual Ideology and the Restoration Actress." English Literary History 46: 595617 .

McKeon, Michael 1995. "Historicizing Patriarchy: The Emergence of Gender Difference in England, 1660-1760." Eighteenth Century Studies 28/3: 295322.

Mora, Maria José 2008. "Was Mary Lee the Woman Turned Bully?" Theatre Notebook 62/1: 4-6.

Mora, Maria José $\mathcal{E}$ al. eds. 2007. The Woman Turned Bully. Barcelona: Publicacions i Edicions Universitat de Barcelona.

Novy, Marianne 1984. Love's Argument: Gender Relations in Shakespeare. Chapel Hill: University of North Carolina at Chapel Hill.

Rosenthal, Laura 1996. "Reading Masks: The Actress and the Spectatrix in Restoration Shakespeare." Ed. Katherine M. Quinsey. Broken Boundaries: Women and Feminism in Restoration Drama. Lexington: The University Press of Kentucky: 203-218.

Rothstein, Eric and Frances Kavenik 1988. The Designs of Carolean Comedy. Carbondale: Southern Illinois University Press.

Shadwell, Thomas 1669. The Royal Shepherdess. London.

Shadwell, Thomas 1993 (1692). The Woman Captain: A Critical Old-Spelling Edition. Eds. Judith B. Slagle and Jack M. Armistead. New York: Garland.

Southerne, Thomas 1988. "Sir Anthony Love." Eds. Robert Jordan and Harold Love. The Works of Thomas Southerne, vol. 1. Oxford: Clarendon Press: 157-257.

Staves, Susan 1979. Players' Scepters: Fictions of Authority in the Restoration. Lincoln: University of Nebraska Press. 


$$
\text { (G) ederi } 22 \text { (2012) }
$$

Stone, Lawrence 1979. The Family, Sex and Marriage in England 1500-1800. Harmondsworth: Penguin.

Weber, Harold M. 1986. The Restoration Rake Hero: Transformations in Sexual Understanding in Seventeenth-Century England. Madison: University of Wisconsin Press.

Williams, Andrew P. 1999. The Image of Manhood in Early Modern Literature: Viewing the Male. Westport: Greenwood Press.

Wilson, John H. 1958. All the King's Ladies. Chicago: University of Chicago Press.

How to cite this article:

Prieto Pablos, Juan Antonio. "Women in breeches and modes of masculinity in Restoration comedy." SEDERI 22 (2012): 69-91.

Author's contact: ppablos@us.es 